\title{
BACILLUS MEGATERIUM BIODEGRADATION GLYCOPHATE
}
N. Mousa ${ }^{*}$
A. $\mathbf{A l i}^{2}$
M. Hussein ${ }^{3}$

${ }^{1,2,3}$ Senior Scientific researcher ; Environment and Water Directorate, Ministry of Science and Technology, Baghdad, Iraq

E-mails: ${ }^{1}$ Nibal.Mousa@mail.co.uk, ${ }^{2}$ Mousa1979@mail.ru, ${ }^{3}$ Whiteflower79@yahoo.com ABSTRACT

This study was aimed to evaluate the Bacillus megatrium ability to growth and degradated the organophosphorus pesticides, Glyphosate. , Bacillus megaterium was isolated from Iraqi Soils and identification by morphological and biochemical tests beside a Sperber's Medium as selectivity media. The best growth results were in (2- 60) days, had the same growth for both $(5,25) \mathrm{ppm}$ on MSM. The best degradation rate ability \% were in (25) $\mathrm{ppm} / 60$ days (70.9)\%. The increasing in incubation show increasing of degradation ration\% of Glyphosate via HPLC specially after 60 days, the best ration were for $(25) \mathrm{ppm}$.The result is the $B$. megaterium used the Glyphosate as source for carbon and phosphorus and suggest could be well exploited for bioremediation of Glyphosate contaminated sites.

Keywords : Organophosphorus-pesticides, Bacteria, Bio-remediation.

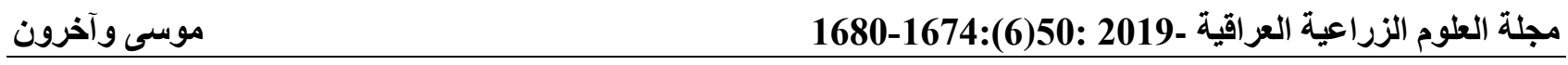

$$
\begin{aligned}
& \text { Bacillus megaterium التحلل الحيوي للكلايفوسفيث بواسطة }
\end{aligned}
$$

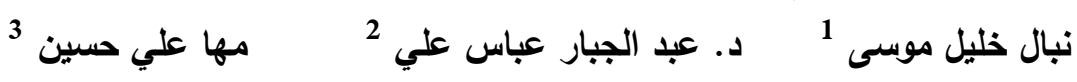

$$
\begin{aligned}
& \text { 2،3، باحث علمي ، دائرة البيئة والمياه ، وزارة العلوم والتكنولوجيا ، بغداد - العراق. }
\end{aligned}
$$

هدفت الدراسة الى تقيم فعالية Bacillus megaterium للنمو والتحطيم لاحد المبيدات العضوية الفسفورية، الكلافوسيت ، حيث تث عزل البكتريا من ترب العراق المحلية واجراء اختبارات الكثف المظهري والحيوي الكيايوي على الوسط الزرعي الانتخابي Sperber’s Medium. كانت النتائج الافضل لنمو البكتريا في (2-60) يوم ولها نفس النمو على التراكيز

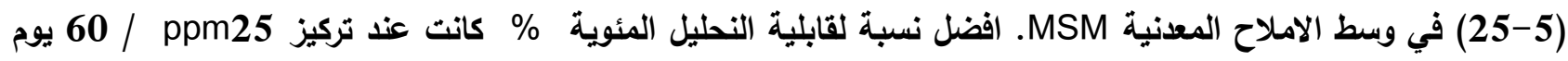
(70.9)\%. ان الزيادة في فترة الحضن اظهرث زيادة في نسبة التحل \% للكلايفوسيت من خلال تحليل جهاز كروموتوغرافيا Bacillus السائل العالي الاداء خصوصا بعد 60 يوم، النسبة الافضل كانت عند تركيز استخدمت الكلايفوسيت كمصدر كاريوني وفسفوري للنمو وممكن استغلالها للتحلل الحيوي للمواقع الملوثة بكلايفوسيث. الكلمات المفتاحية: مبيدات الفسفور العضوية، البكتريا، التحلل الحيوي. 


\section{INTRODUCTION}

Organophosphate pesticides are heterogeneous compounds, containing a phosphoric acid derivative. ;Glyphosate is one of an organophosphate and non-selective herbicide , applied to the leaves of plants for killing both broadleaf plants and grasses .It was first registered for use in the U.S. in 1974 by Monsanto (Roundup) (18). Glyphosate stops a specific enzyme pathway, the shikimic acid pathway. The shikimic acid pathway is necessary for plants and some microorganisms. Beside the benefits of Using chemicals in pests control, they can cause potential human and environmental in case of extensive use (9). The genotoxicity and carcinogenicity studies for glyphosate and its commercial products (Roundup) were assessed. There was no convincing evidence for direct DNA damage in vitro or in vivo, and it was concluded that Roundup and its components do not pose a risk for various types of cancer in humans1.Glyphosate is difficult herbicide in trace analysis, has low molecular weight, low volatility, thermal lability, and good water solubility. These properties cause problems in extraction, purification and determination (9). The ability of Microorganism to remove pollutants from contaminated sites is one of promising treatment method (7).As an alternative strategy, is supported because of their effectiveness, minimize hazardous , economic value and environmental safety is known bioremediation (5) .Many researcher improved that different bacteria groups shown great ability of degradation Organophosphorus insecticides and others $(3,6,15,19)$. The microorganisms strategies in degradation reaction towards pesticides in soils and they are co- metabolism, catabolism and metabolic enzymes (4). To determine the fate for pesticides in environmental, the microbial degradation can be a base factor for that., the study aim to carried out to investigate the ability of local bacterial isolated to tolerate and degrade Glyphosate in different concentrations and value the residue of it in extraction solution from media by HPLC.

\section{MATERIAL AND METHODS \\ Chemical and reagents}

Commercial pesticide "Glyphosate "was purchase from Iraqi market and other chemicals and reagents were in laboratories of Water and Environmental Directorate of Iraqi Ministry of Science and Technology. The media that used in growing $B$. megaterium to examine Glyphosate degradation was Mineral Salt Media(MSM) $\left(0.2\right.$ g $\mathrm{KH}_{2} \mathrm{PO}_{4} ; 0.5 \mathrm{~g}$ $\mathrm{K}_{2} \mathrm{HPO}_{4}$ (sterilized separately at $125^{\circ} \mathrm{C}$ for 25 min to prevent precipitation and later aseptically added to the rest of the salts); $1 \mathrm{~g}$ $\left(\mathrm{NH}_{4}\right)_{2} \mathrm{SO}_{4} ; 0.2 \mathrm{~g} \mathrm{MgSO}_{4} \cdot 7 \mathrm{H}_{2} \mathrm{O} ; 0.2 \mathrm{~g} \mathrm{NaCl}$; $0.05 \mathrm{~g} \mathrm{CaCl}_{2} \cdot 2 \mathrm{H}_{2} \mathrm{O} ; 0.025 \mathrm{~g} \mathrm{FeSO}_{4} \cdot 7 \mathrm{H}_{2} \mathrm{O}$; $0.005 \mathrm{~g} \mathrm{Na}_{2} \mathrm{MoO}_{4} ; 0.0005 \mathrm{~g} \mathrm{MnSO}_{4}(\mathrm{pH} 7.0 \pm$ $0.3)$ (10). Flasks(125mL)were supplemented with Glph (Glyphosate) as the only carbon source. The Final Concentration of Glph were $(5,10,15,20,25 \mathrm{ppm})$ with $0.5 \mathrm{ml}$ from inoculum bacteria in comparative with control.

\section{Soil samples collection}

Samples were taken from the top $15 \mathrm{~cm}$ of soil and kept in plastic bags at $4 \circ \mathrm{C}$ until use. Different samples of soil were collected treated and non-treated with organophosphorus pesticides and used for isolation microorganism by dilution (7).

\section{Isolation and identification of Bacillus megaterium from soil}

Bacillus megaterium was isolated by Sperber's Medium which is a selective medium for isolating it. The Sperber Media consist of :( Glucose - $10 \mathrm{~g}$ Yeast extract - $0.5 \mathrm{~g} \mathrm{MgSO}_{4}$. $7 \mathrm{H}_{2} \mathrm{O}-0.25 \mathrm{~g} \mathrm{CaCl}_{2}-0.1 \mathrm{~g}$ Agar $-15 \mathrm{~g}$ Distilled water - $1000 \mathrm{ml}, \mathrm{pH}-7.0-7.2 \mathrm{Add}$ $10 \% \mathrm{CaCl}_{2} 3 \mathrm{ml} / 100 \mathrm{ml}$ and $10 \% \mathrm{~K}_{2} \mathrm{HPO}_{4}-2$ $\mathrm{ml} / 100 \mathrm{ml}$ before pouring to the plates.)(11). The inoculated plates were incubated at 28$30^{\circ} \mathrm{C}$ for $48 \mathrm{hrs}$. At the end of the incubation period number of colonies of Bacillus megaterium appearing on the plates were observed (11). The cultures so isolated were characterized through a number of morphological, microbiological and biochemical tests. Aerobic spore formers pasteurize a diluted soil sample at 80 degrees for 15 minutes, then plated onto nutrient agar and incubated at $37^{\circ} \mathrm{C}$ for $24 \mathrm{hrs}$. The plates were examined after $24 \mathrm{hrs}$. for typical colonies identified as catalase-positive, Grampositive, endospore-forming rods (7). 


\section{Bacillus megaterium Growth and degradation Glph in MSM}

The hydrolysis capacity was measured $(2,5,7,14,21,30,60)$ days by spectrophotometer OD 600 , and the extraction of Glph residue from MSM were in 30 and 60 day by added equal volume from media and ethyl acetate as extraction reagent in tube with twice time extraction, The mixture was centrifuged at $3000 \mathrm{rpm}$ for ten minutes. The ethyl acetate with residual Glph was filtered and dried with anhydrous sodium sulfate followed by filtration through glass-fiber paper (Whatman GF/B). This operation was conducted sequentially and the filtrates were mixed (10). The degradation ratio $(\%)$, were measured for Glph according to equation 1

$P=\left(1-\frac{C 1}{C 0}\right) x 100 \%$

$P=$ refered to the degradation rate of Glph ,
$C l=$ account for Glph concentration of treated test sample.

$\mathrm{CO}=$ account for the control (13).

\section{Metabolite analysis}

Each of extraction by ethyl acetate were analyzed by HPLC .Chromatography determination were with a UV-Vis detector at $254 \mathrm{~nm}$ and a manual injector equipped with a $20-\mu \mathrm{L}$ loop, using a C-18 ZORBAX column $(5 \mu \mathrm{m} ; 150 \mathrm{~mm} \times 4.6 \mathrm{~mm}$ i.d. $)$ from Agilen Technologies as stationary phase. The mobile phase used was prepared by mixing acetic acid $(1 \%)$ with methanol in a 60:40 ratio (v/v). The flow rate used was $1.0 \mathrm{~mL}$ min-1, stabilized at constant temperature $23-25^{\circ} \mathrm{C}(8)$.

RESULTS AND DISCUSSION Morphological and Biochemical tests

Beside used the selective media, Sperber's Medium, The Morphological Test, Table 1 and biochemical tests, as in Table 2.

Table 1. The Morphological tests

\begin{tabular}{|ll|}
\hline & \\
\hline Spore shape & Rod-like/ flagella spores \\
Colonies & Round to irregular /yellow to brown or black after prolonged incubation \\
Motility & + \\
Gram stain & + \\
Aerobic & + \\
Temperature & $3-20^{\circ} \mathrm{C} / 35-45^{\circ} \mathrm{C},{\text { optimun } 30^{\circ} \mathrm{C}}^{\circ}$ \\
pH & $5^{-7-7}$ \\
\hline
\end{tabular}

Table 2. The Biochemical tests

\begin{tabular}{|lcll|}
\hline \multicolumn{4}{c|}{ Biochemical tests } \\
\hline Catalase & + & Nitrate reduction / Degradation of tyrosine & $+/-$ \\
Starch Hydrolysis & + & Casien hydrolysis & + \\
Citrate utilization & + & Indol/ Methyl Red & - \\
Esculin hydrolysis & + & Arginine dihydrolase & - \\
Gelatin hydrolysis & + & Tryptophan deaminase & - \\
Oxidase & + & Hydrolysis Urea & - \\
\hline
\end{tabular}

Bacillus megaterium hydrolyzes and 25) $\mathrm{ppm}(0.164,0.167)$ respectively, while the bacteria growth

\section{Growth of $B$. megaterium}

The results show that the best growth of $B$. megaterium were in (60 days) for both (5,
$15 \mathrm{ppm}$ show the highest growth in 60 day $(0.215)$ in comparative with others when used Glph as a carbon sources figure 1 . 


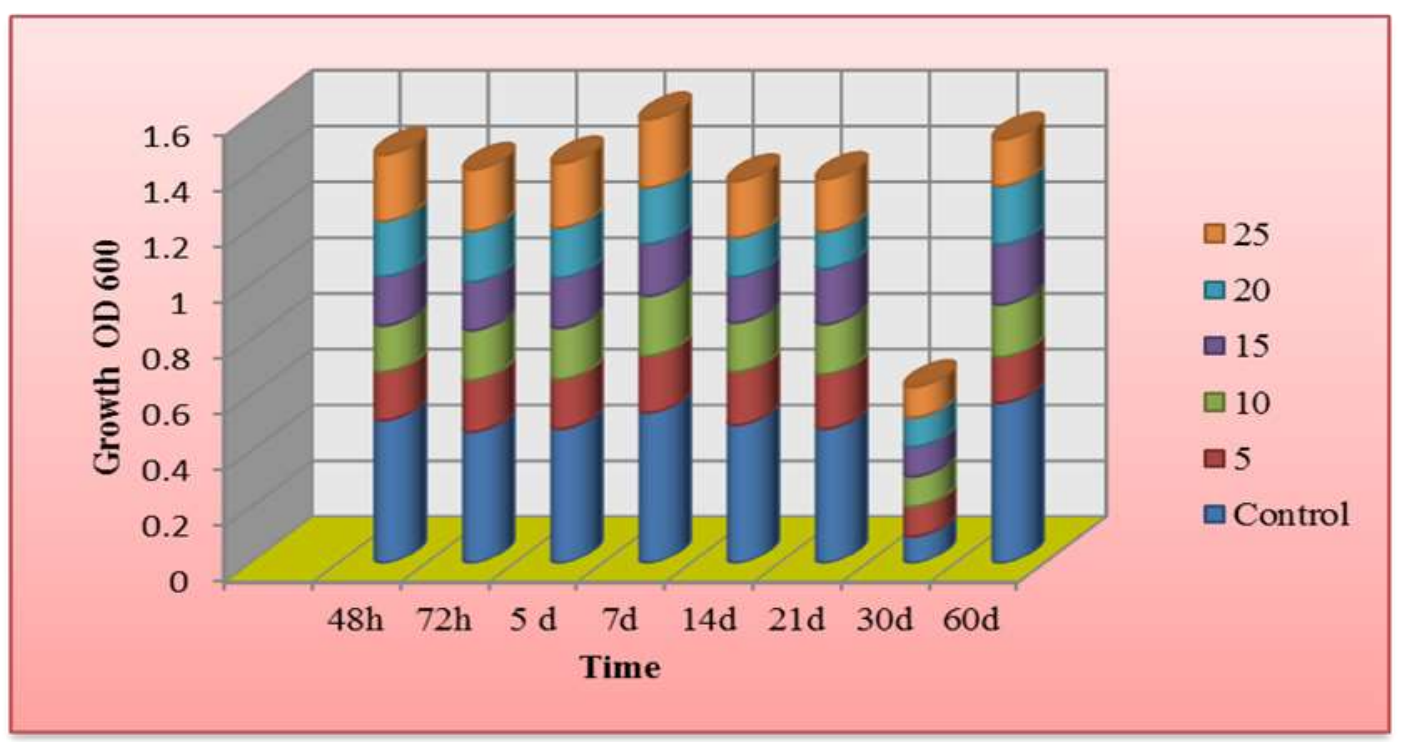

Figure 1. Growth of B. megaterium on MSM containing GIph

\section{B. Degradation rate \%}

The results show that the best degradation rate\% for Glph by $B$. megaterium in comparative among concentration were for both the 5-25 ppm in 60 day reached (70.01$70.9) \%$, figure 2.

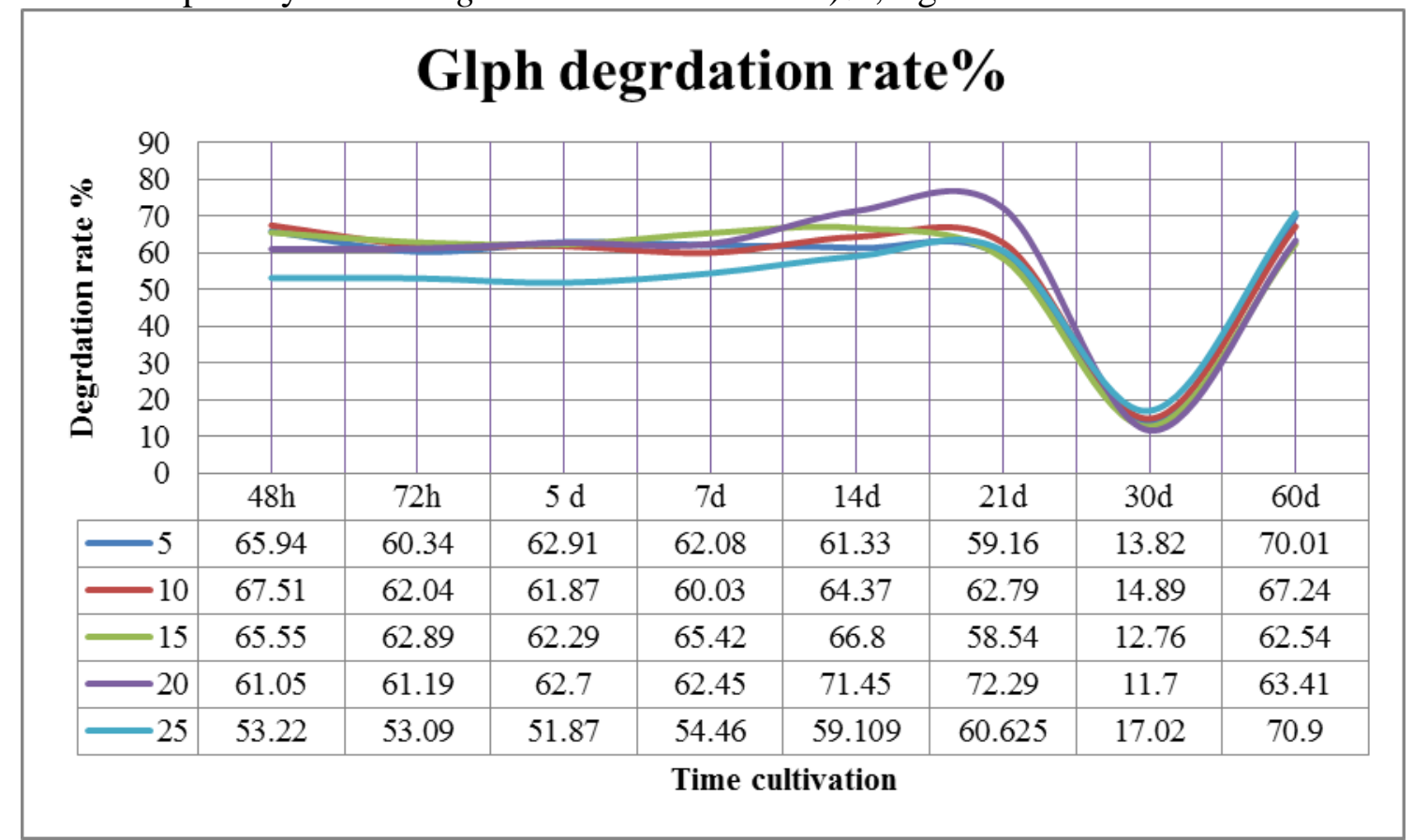

Figure 2. Degradation rate of GIph in MSM in Comparative with control

\section{Glyphosate residues by HPLC test}

The study showed that B.M. has grown on $(5,10,15,20,25) \mathrm{ppm}$ concentration of Glph in MSM at $30{ }^{\circ} \mathrm{C}$, as the growth of bacteria increased the concentration decreased generally in MSM with Glph in comparative with control in Fig $(3,4)$. The best peak area that showed decreasing in Glph in $30 \mathrm{~d}$ were for concentration $(5,10) \mathrm{ppm}(7,8) \%$,while the $25 \mathrm{ppm}$ showed $28 \%$, while the results of
Glph peak area for B.M. incubation for 60 days on MSM, showed the best for $(20,15)$ ppm in comparative with control. When compare among the Glph Concentration's via HPLC and degradation ratio\% in Fig $(5,6)$, showed when increase the time incubation to 60 days, the Bacillus megaterium degradation ratio\% increased for all Glph concentration's , but the best were for $(5,25) \mathrm{ppm}$ for both the HPLC analysis and Degradation ration\%. 


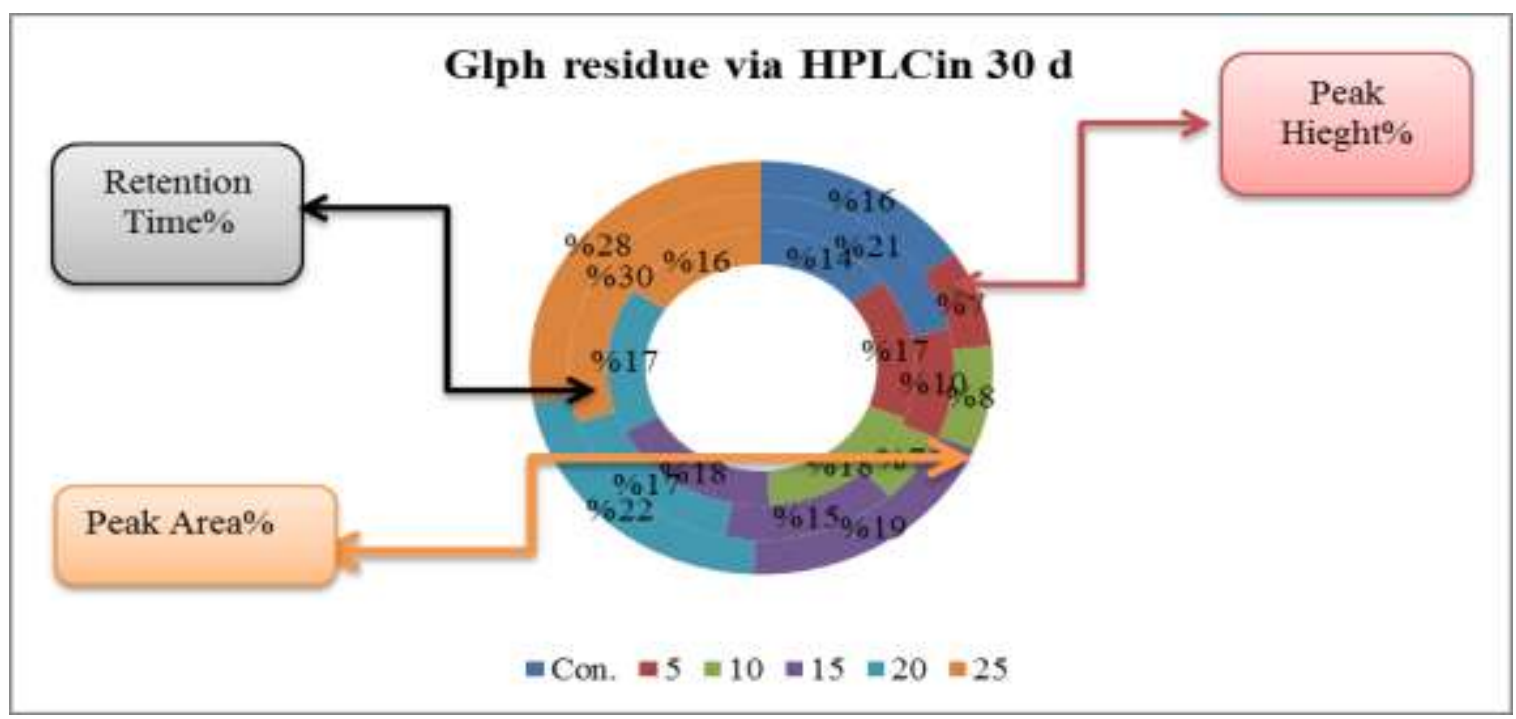

Figure 3. Retention time, peak area and peak height of $(5,10,15,20,25$ ppm+control) dilution of Glph after incubation B.M. 30days in MSM

\section{Glph risdues via HPLC in $60 \mathrm{~d}$}

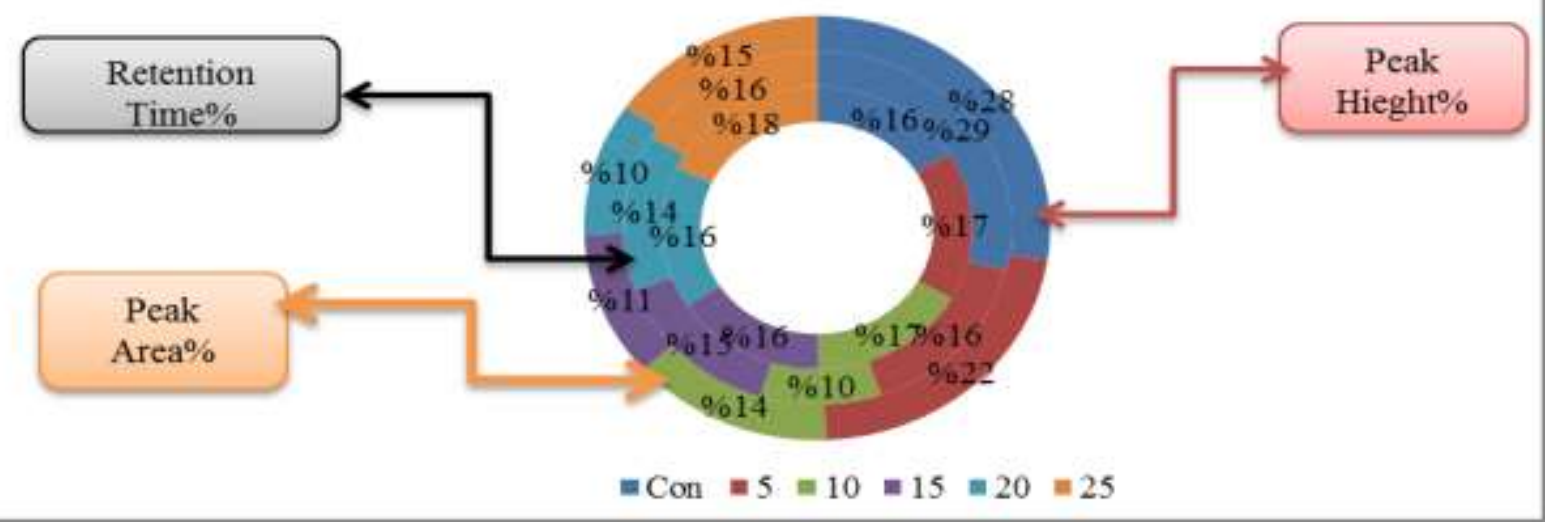

Figure 4. Retention time, peak area and peak height of $(5,10,15,20,25$ ppm+control) dilution of Glph after incubation B.M. 60days in MSM

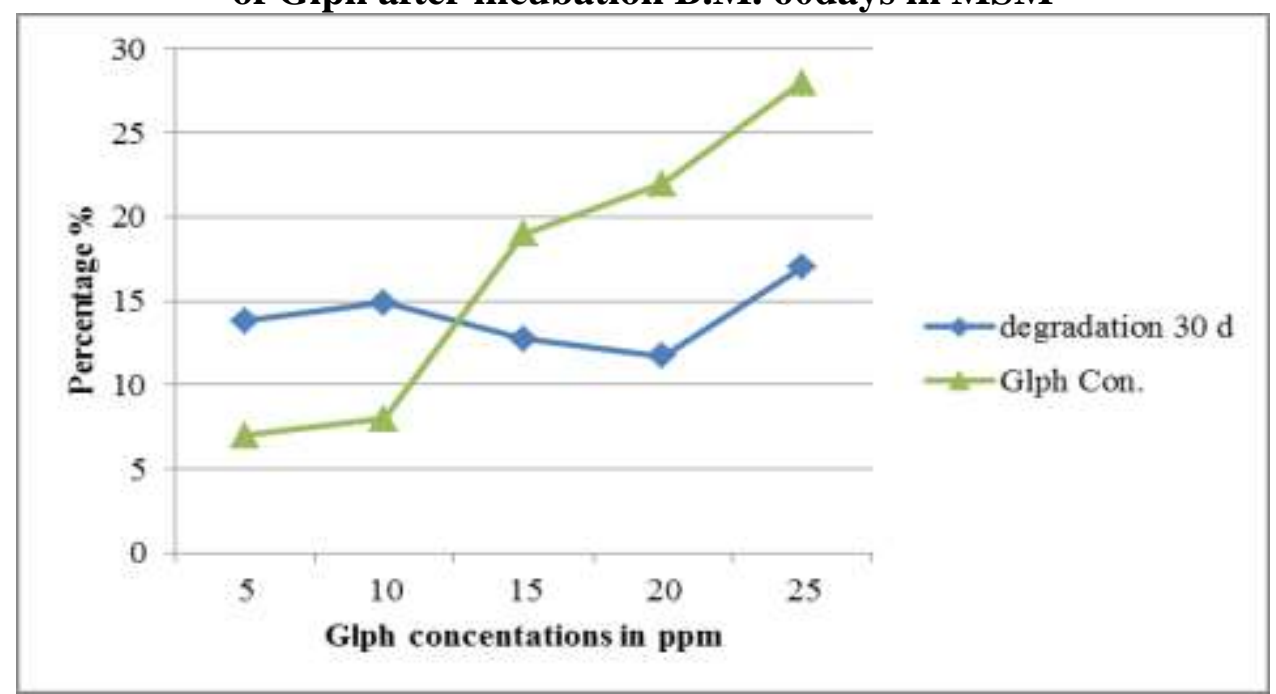

Figure 5. Comparative among the degradation ratio\% and Glph concentrations via HPLC in 30 days incubation on MSM 


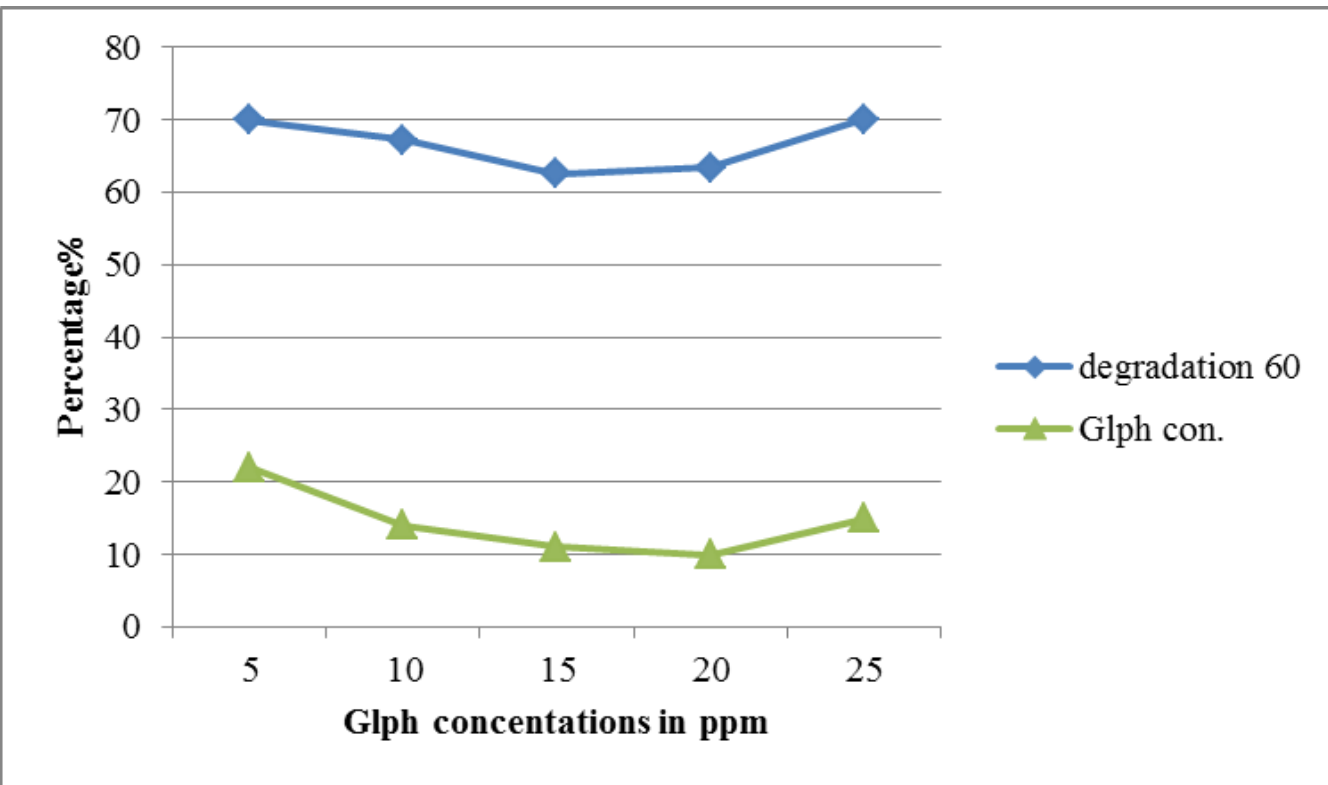

Figure 6. Comparative among the degradation rqtio\% and Glph concentation via HPLC in 60 days incubation on MSM

Microbial degradation of organophosphorus pesticides and the development of bioremediation strategies for polluted agricultural soils based upon the introduction of biodegrading microorganisms, represent a growing area of research worldwide (15) . B. megaterium shows highest growth and degradation rate $\%$ in 60 days cultivation time for both 5,25 ppm concentration. The ability of degradation organophosphate pesticide like Chlorpyrifos by B. megaterium for $600 \mathrm{mgL}$ 1 concentrations, was $81 \%$ in 10 days incubation (16), while B. M. show in 20 ppm /21days 72.29. In other study the B.M. Improve significant degradation ability towards atrazine $(50 \mathrm{mg} / \mathrm{kg})$ could reach $99.0 \%$ by the microbial agent after 7 days(17). The bacteria show increasing in growth with corresponding increase in glyphosate concentration while B. subtillus show reduction in growth with corresponding increase in glyphosate concentration(18). Other study, showed B.megaterium ability to degradation other organophosphore pesticides, Chlorpyrifos in $7-14$ days, will be potentially useful in abatement of Chlorpyrifos

\section{REFERENCES}

1.Bhadbhade B.J, Sarnaik S.S., Kanekar, P.P. , 2002, Biomineralization of an organophosphorus pesticide, Monocrotophos, by soil bacteria. J Appl Microbiol. ;93(2):22434.

2.Chandrashekar ,M.A.,Supreeth,M., Soumya Pai,K., Ramesh ,S.K.C.,Geetha ,N., Puttaraju contaminated soil (19).Monocrotophos(MCP), also degraded to carbon dioxide, ammonium and phosphate through formation of unknown compound metabolic by $B$. megaterium, reached $83 \%$ (20). In this study, Bacillus megaterium was isolated from Iraqi Soils and identification by morphological and biochemical tests beside a Sperber's Medium as selectivity media to B.M. The best results for growth B.M. were in $48 \mathrm{~h}$ while in 60 days had the same growth for both 5,25 ppm on MSM. The degradation rate $\%$ ability were the best in $(5,25) \mathrm{ppm} / 60$ days $(70.01-70.9) \%$. The Glyphosate Concentrations via HPLC and degradation ratio $\%$, showed when increasing the time incubation to 60 days, the Bacillus megaterium degradation ratio\% increased for all Glyphosate concentration's, but the best were for $(5,25) \mathrm{ppm}$ for both the HPLC analysis and Degradation ration\%. From all the conclusion is that the $B$. megaterium used the Glyphosate as source for carbon and phosphorus and suggest could be well exploited for bioremediation of Glyphosate contaminated sites.

,H.R.,and Raju,N.S.,2017, Biodegradation Of Organophosphorous Pesticide,Chlorpyrifos By Soil Bacterium - Bacillus Megateriumrc 88 . Asian Jr. of Microbiol. Biotech. Env. Sc., 19(1), 127-133

3.Comeau, Y., Greer,C.W., and Samson,R. 1993, Role of inoculum preparation and density on the bioremediation of 2,4-D contaminated 
soil by bioaugmentation. Appl. Microbiol. Technol., 38: 681-687

4.El-Sheikh, E.A. and Ashour , M.B.,2010, Biodegradation Technology for Pesticide Toxicity Elimination. In: Bioremediation Technology-Recent Advances, M.H. Fulker (Editor). Capital Publishing Company, New Delhi, 162-205

5.Finley, S. D.,Broadbelt L. J., and Hatzimanikatis , V.,2010, In Silico Feasibility of Novel Biodegradation Pathways for 1,2,41140 Ibrahim, et al. Trichlorobenzene. BMC Systems Biology, 4 (7): 4-14

6.Ghassempour, A., A. Mohammadkhah, F. Najafi and Rajabzadeh ,M., 2002, Monitoring of the pesticide diazinon in soil, stem and surface water of rice fields. Anal. Sci., 18: 779-783

7.Ibrahim, G.A.G., Amin, M.K., A.A. Hassan and El-Sheikh. E.A.,2015, Identification Of Pesticides Degrading Bacteria Isolated from Egyptian Soil. Zagazig J. Agric. Res.,42 (5), 1129-1143

8.Islas, G., Rodriguez J.A.,Mendoza Huizar,L.H., Pérez-Moreno,F., and Gabriela Carrillo,E.,.2014,Determination Of Glyphosate and aminomethylphosphonic acid in soils by HPLC with pre-column derivatization using 1,2-Naphthoquinone-4-Sulfonate. Journal of Liquid Chromatography \& Related Technologies, 37:1298-1309

9.Kaczyński, P. and Łozowicka, B., 2015, Liquid chromatographic determination of glyphosate and aminomethylphosphonic acid residues in rapeseed with MS/MS detection or derivatization/fluorescence detection. Open Chem., 13: 1011-1019

10.Mkpuma ,D.U.M., and Simeon,V.O.E. .2015. Isolation, Characterization and Biodegradation Assay of Glyphosate Utilizing Bacteria from Exposed Rice Farm. Journal of Biology, Agriculture and Healthcare, 5(5):96109

11.Nieminen, T., Rintaluoma, N., Andersson, M., Taimisto, A.M., Ali-Vehmas, T., Seppälä, A., Priha, O., Salkinoja-Salonen,M.,2007, Toxinogenic Bacillus pumilus and Bacillus licheniformis from mastitic milk.Vet Microbiol,124(3-4):329-339
12.Ortiz-Hernández, M.L., And SánchezSalinas,E., 2010, Biodegradation Of The Organophosphate Pesticide Tetrachlorvinphos By Bacteria Isolated From Agricultural Soils In México. Rev. Int. Contam. Ambient. 26 (1) 27-38

13.Semple, K.T., Reid, B.J. and Fermor, T.R., 2001, Impact of composting strategies on the treatment of soils contaminated with organic pollutants. Environ Pollut,112:269-83

14.Shweta,N., Jadhav, S.K. and Keshavkant S, 2017,Bacillus megaterium: A potential swimmer and an efficient bio-degrader of an organophosphorus pesticide. International Conference on Environmental Microbiology and Microbial Ecology and International Conference on Ecology and Ecosystems,7, Issue 2 ; page 84

15.Sørensen, S.R., Albers,C.N., and Aamand,J., 2008, Rapid mineralization of the phenylurea herbicide diuron by Variovorax sp. strain SRS16 in pure culture and within a twomember consortium. Appl. Environ. Microbiol., 74: 2332-2340

16.Sperber, J. I., 1957, Solubilization of mineral phosphate by soil bacteria. Nature, 180: 994-995

17.Tang M., and You M. , 2012, Isolation, identification and characterization of a novel triazophos-degrading Bacillus sp. (TAP-1). Microbilogical Research ,167:299-305

18.Valavanidis, A., 2018, Glyphosate, the Most Widely Used Herbicide. Scientific Reviews. ,Chem-toxecotox. org. pages: 41

19.Yasouri, F.N., 2006, Plasmid mediated degradation of diazinon by three bacterial strains Pseudomonas sp., Flavobacterium sp. and Agrobacterium sp. Asian J. Chem., 18: 2437-2444.

20.Zhu,J. ,Fu,L.,Jin,C.,Meng,Z., and Yang,N., 2019, Study on the Isolation of Two AtrazineDegrading Bacteria and the Development of a Microbial Agent. Microorganisms, 7,80:1-11 